\title{
The relationship between house dust mites and environmental factors beyond the analysis power of a skin prick test
}

\author{
Sevilay Oguz Kılıç', Meliha Merve Hiz Çiçekliyurt² ${ }^{2}$ Sibel Oymak Yalçın³ \\ 'Department of Dermatology, Faculty of Medicine, Çanakkale Onsekiz Mart University, Çanakkale, Turkey \\ ${ }^{2}$ Department of Medical Biology, Faculty of Medicine, Çanakkale Onsekiz Mart University, Çanakkale, Turkey \\ ${ }^{3}$ Department of Public Health, Faculty of Medicine, Çanakkale Onsekiz Mart University, Çanakkale, Turkey
}

\section{ABSTRACT}

Introduction: The house dust mite is a major cause of allergic disease. The standard diagnostic techniques consist of determination of the immunoglobulin E ( IgE) level in blood and the application of a skin prick test. The skin prick test results are not always reliable because only 2 common species are determined by the test. Thus, the prevalence of mite allergy in a population requires microscopic analysis of collected samples.

Aim: This cross-sectional study was conducted to investigate whether skin prick test results are compatible or not with the presence of mites in a house.

Material and methods: A total of 84 allergic patients were included in the study. A questionnaire was applied to detect allergic risk factors. The skin prick test was performed to ascertain if the allergy occurs due to Dermatophagoides pteronyssinus and D. farinae. Patients were requested to take dust samples from their homes to determine the sensitivity of the prick test.

Results: In our study, we have shown that D. pteronyssinus and D. Farinae are the common (32.5\%), but not the only species, in dust samples. The frequency of mites was found to be $21.4 \%$ in dust samples taken from the homes of these patients, and $17.5 \%$ of the house dust mite allergen could not be identified without microscopic examination. In this study, we have clearly shown that humidity and feeding animals increase the dust mite development risk by 1.74 and 1.82 times, respectively.

Conclusions: Dermatologists should request dust samples from patients with allergic problems for detailed examination such as microscopy or ELISA.

\section{KEY WORDS}

mite, Dermatophagoides, atopic dermatitis, Dermatophagoides farinae, Dermatophagoides pteronyssinus.

\section{ADDRESS FOR CORRESPONDENCE}

Meliha Merve Hiz, Department of Medical Biology, Faculty of Medicine, Çanakkale Onsekiz Mart University, Çanakkale, Turkey, phone: +90 5332444545, e-mail: mervemeliha@comu.edu.tr 


\section{INTRODUCTION}

Allergic disease is the fastest growing chronic disease and global public health problem that is caused by hypersensitivity of the immune system. The prevalence of allergic diseases and related disorders is increasing all over the world. If effective allergy treatment cannot be achieved, patients might have serious health problems such as dermatitis, rhinitis, gastric problems, chronic urticaria, asthma, and anaphylaxis [1-5]. Allergic diseases impair the life quality of patients and also affect the economies of the countries [1].

House dust is an allergen that consists of many biotic and abiotic materials such as mites, pollens, mould spores, animal dander, dried food particles, and fabric fibres [6]. These aeroallergens cause irritation in the respiratory tract, mucosae, or skin of the patient [7]. The parts of house mites and mite-derived molecules are the potential allergens in dust due to their protein-based structure, and they have protease activity that can influence the epidermal permeability $[6,8]$. In fact, house dust mites never bite or transmit any kind of disease, like flies do. In contrast, house dust mites trigger immune reaction via their faeces and exoskeleton and cause wheezing and/or allergy in humans [9]. Nowadays, immunotherapy tablets are advised to use desensitization reactions for house dust mites $[5,10$, 11]. The efficacy of allergen immunotherapy is well documented, and the route of administration is advised as subcutaneous and sublingual against house dust mites [11].

House dust mites are microscopic arachnids that belong to a family of Pyroglyphidae. The total number of house dust mites is estimated at about 55,000 species, but only $5 \%$ of them have been identified. Five percent of the world population is susceptible to mite allergens. The Dermatophagoides genus is considered as the main cause of house dust sensitivity Dermatophagoides pteronyssinus (Trouessart), Dermatophagoides farina (Hughes), and Euroglyphus maynei (Cooreman) are the most prevalent species found in house dust [4, 9]. A prick test is applied to determine the role of mites in allergic diseases. $D$. pteronyssinus and $D$. farinae are the most common house dust mite allergens; thus, these are both widely used in the skin prick test [11]. The skin prick test is a non-invasive, common procedure in allergy practice [12], but the power of the prick test to determine mite allergens is weak due to its false positive and negative results. Thus, in that study studied examine the house dust samples under a microscope to understand the efficiency of the skin prick test.

\section{AIM}

The aim of the study was to evaluate firstly the success of the prick test to determine house dust allergy. In ad- dition, the study was designed to find out the prevalence of house dust mites and assess the independent factors related to house dust mites to show the relative risk of these factors to dust allergy.

\section{MATERIAL AND METHODS}

\section{STUDY DESIGN AND PATIENT POPULATION}

Patients were recruited from the Dermatology Clinics of University Medical Faculty Hospital. Eighty-four of the patients who were diagnosed with allergy were included in the study between May 2017 and 2019. The questionnaires were applied to patients who agreed to collect dust samples from their homes. The questionnaire took 10-15 min and consisted of 20 questions that describe the demographic characteristics of patients. A detailed physical examination and face-to-face interview were applied to detect the allergic risk factors of participants. The inclusion criteria were not using drugs including antihistamines, corticosteroids, bronchodilators, mast cell stabilizers, and immunosuppressive agents in the last 15 days before the skin prick test. This study was approved by the Institutional Ethics Committee of the University (2011-KAEK-27/2017-E.26343-05/04) on 3 March 2017.

\section{SKIN PRICK TEST}

The skin prick tests were used to determine the allergic response to $D$. pteronyssinus and $D$. farinae. The test was carried out on the inner forearm - a drop of allergen solution was dripped from $2 \mathrm{~cm}$ and placed on the skin of the participants. Positive and negative control samples were also applied at the same time to detect the accuracy of the test. The positive control solution contained histamine hydrochloride $(10 \mathrm{mg} / \mathrm{ml})$ and reacted in all people. Negative control solutions consisted of antigen dilution solutions, and none of the people reacted to it. The results of the skin test were evaluated by comparison of the positive controls plaques (histamine reactions) with the allergen reactions. Skin reactions were recorded after $15 \mathrm{~min}$. The reactions of the skin such as erythema and oedema were evaluated by dermatologists. If the allergen reaction reached at least half the diameter papules of urticarial papules of the positive control, then it was considered as a positive immunological skin reaction.

\section{COLLECTION AND ANALYSIS OF DUST SAMPLES}

House dust samples were requested to be collected from various parts of the house under the bed, carpets, and rugs in the room by broom or vacuum. House dust samples were collected in a transparent, resealable plastic 
bag of size $20 \times 50 \mathrm{~cm}$, and the mouth of the bag was closed tightly and collected from the participants within $6 \mathrm{~h}$ of sampling. All samples were kept in a refrigerator until microscopic examination. The mites were separated from dust by Spieksma-Boezaman's method of modified lactic acid precipitation [13]. $100 \mathrm{mg}$ of dust sample were transferred to petri dishes, and $5 \mathrm{ml}$ of $90 \%$ lactic acid solution was prepared in a test tube at the same time. Each gram of dust sample was added to a lactic acid solution in a tube and placed in a stand with gentle stirring at $70-80^{\circ} \mathrm{C}$ for $1 \mathrm{~h}$. Samples were taken from the liquid surface, and the bottom portion was analysed. The microscopic examination of mites performed by the slide of the samples under light microscopes with $10 \times, 20 \times$, and $40 \times$ magnification. Any type of mite was considered positive in the presence of adults, larvae, or eggs.

\section{STATISTICAL ANALYSIS}

The obtained data analysis was performed by using SPSS software version 19.0. The normal distribution of variables was analysed to conform with the Kolmogorov-Smirnov test. The mean, standard deviation, minimum, and maximum of the variable were used to identify descriptive data. The relationship between the presence of house dust mites by skin prick test result was analysed using Fisher's exact test analysis. The $p$-value of less than 0.05 was considered statistically significant. Odds ratios (ORs) and 95\% confidence was used to estimate the risk of atopic dermatitis, allergic rhinitis, allergic conjunctivitis, and allergic asthma in the presence of house dust mites. Relative risk (RRs) was used to compare the risks of allergy in special conditions.

\section{RESULTS}

We studied 84 patients aged 4 to 67 years with a mild-to-moderate allergy, to determine if house dust mites are risk factors and having positive allergy skin test responses to indoor allergens. The median age of patients was $25.5 \pm 19.1$ years. The patients were predominantly female (58.3\%). The average of the total IgE level was $262.06 \pm 365.47 \mathrm{kU} / \mathrm{l}$, ranging from 3.21 to $2000 \mathrm{kU} / \mathrm{l}$. The prick test was applied to 81 patients, and 3 patients rejected the skin prick test. Sixty-three patients, who agreed to collect dust samples from their homes, replied to the questionnaire.

The frequency of mites was $21.4 \%$ in dust samples taken from the homes of these patients. We evaluated the specific allergic diseases risk (i.e. atopic dermatitis) with all allergic reactions that were seen in the study group. In our study, we found that the house dust mite triggers all kinds of allergies without any specifier (Table 1).
Of the 84 patients, $13.3 \%$ were current smokers and $7.2 \%$ were ex-smokers. The question "Does anyone smoke in your home? If yes, are you exposed to cigarette smoke at home?" was answered positively by 29 of the 84 patients. Inhalation of cigarette smoke increases the mite development risk 1.2-fold, but the difference was not statistically significant $(\mathrm{OR}=1.22$; $95 \%$ CI: $0.71-2.08$, $p=0.47)$.

We asked "How many times in a week do you sweep in your home?" to determine if the participant interfered with mites during sleep or breathing? We recived the following answers: 22 (26.5\%) of the participants were asleep at home 2 times, 16 (19.3\%) of them 7 times, $12(14.5 \%)$ people 3 times, 12 (14.5\%) people 4 times, 12 (14.5\%) people 1 time, 8 (9.6\%) people 5 times, and only $1(1.2 \%)$ person 6 times. And following this question, we asked "How do you sweep your home?" The answers to the question were as follows: $66(79.5 \%)$ people with bagged and dust chamber cleaner, 12 (14.5\%) people with a water tank cleaner, and 3 (3.6\%) with a hand cleaner. The type of sweeper did not affect the risk of mite development (Table 2).

The aeration of the bedroom is important to limit the development of mites' germs. To evaluate the association between aeration of the room and the presence of mites, we asked "How often do you aerate your bedroom?" Sixty-four $(77.1 \%)$ participants reported that they aerate the bedroom every day. Thirteen (15.7\%) of the participants reported that they aerate their bedrooms every 1 or 2 days, while $6(7.2 \%)$ people aerated in changing times. When we compared the groups that aerated their rooms every 2 days with the ones aerated every day, we found 1.63-fold higher mite development risk, but this was not statistically significant ( $\mathrm{RR}=1.63$; 95\% CI: 0.41-6.46; $p=0.49)$. We also evaluated the aeration of the children's rooms. Of the 84 participants, $46(71.9 \%)$ aerated the children's room every day, 14 (21.9\%) of them reported that aeration was done every 1 or 2 days, and 4 (6.3\%) people aerated in changing times. Also, we could not find any association between the children's room aeration and mite development $(\mathrm{RR}=1.63$; 95\% CI: $0.48-5.55 ; p=$ $0.43)$. The third question about the aeration was "How many times in a week do you aerate your living room?" Sixty-six $(81.5 \%)$ of the participants reported that they aerate their living room every day, while 11 (13.6\%) of them aerate every 1 or 2 days, and 4 (4.9\%) of them aerated in changing times. When we compared the groups that aerated their living rooms less than once a day with the others who aerated daily we could not find any association with living room aeration and house dust mite development $(\mathrm{RR}=0.80 ; 95 \% \mathrm{CI}: 0.22-2.95 ; p=0.74)$. The aeration period of the rooms was not affected by mite development statistically within subgroups. 
TABLE 1. The distribution of allergic disease and the risk of disease in the presence of mites

\begin{tabular}{|l|c|c|c|}
\hline Disease diagnosis & Number (\%) & Odds ratio & $95 \%$ Cl; $p$-value \\
\hline Atopic dermatitis & $23(23.5)$ & 1.33 & $0.47-3.83 ; 0.59$ \\
\hline Allergic rhinitis & $55(56.1)$ & 0.61 & $0.23-1.63 ; 0.32$ \\
\hline Allergic conjunctivitis & $7(7.1)$ & 0.65 & $0.10-4.14 ; 0.64$ \\
\hline Allergic asthma & $13(13.3)$ & 0.80 & $0.22-2.95 ; 0.74$ \\
\hline Urticaria & $10(11.9)$ & 0.37 & $0.089-1.58 ; 0.18$ \\
\hline
\end{tabular}

TABLE 2. Association of house dust-related parameters and mite development risk

\begin{tabular}{|c|c|c|c|c|}
\hline \multirow[t]{2}{*}{ Variables } & \multicolumn{2}{|c|}{ House mite } & \multirow[t]{2}{*}{ Relative risk ratio } & \multirow[t]{2}{*}{$95 \% \mathrm{Cl}, p$-value } \\
\hline & Presence & Absence & & \\
\hline \multicolumn{5}{|l|}{ Pillowcase type: } \\
\hline Wool ${ }^{\mathrm{a}}$ & 18 & 21 & $\mathrm{RR}^{\mathrm{a} \text { vs.b: }}: 2.17$ & $1.54-3.04 ;<0.001$ \\
\hline Cotton $^{b}$ & 1 & 1 & $\mathrm{RR}^{\mathrm{a} \text { vs. c. }} 2.0$ & $1.08-3.72 ; 0.03$ \\
\hline Fibre $^{c}$ & 5 & 5 & $\mathrm{RR}^{\text {a vs.c: }} 1.86$ & $1.13-3.07 ; 0.016$ \\
\hline Mixed $^{d}$ & 7 & 6 & & \\
\hline \multicolumn{5}{|l|}{ Pillow type: } \\
\hline Wool $^{\mathrm{a}}$ & 3 & 3 & $\mathrm{RR}^{\text {a vs. b: }} 1.06$ & $0.41-2.74 ; 0.90$ \\
\hline Cotton $^{b}$ & 8 & 9 & $\mathrm{RR}^{\text {a vs. c. }: 1.0}$ & $0.42-2.4 ; 1.0$ \\
\hline Fibre $^{c}$ & 15 & 15 & $\mathrm{RR}^{\text {avs. d: }} 1.0$ & $0.36-2.75 ; 1.0$ \\
\hline Mixed $^{d}$ & 5 & 5 & & \\
\hline 0thers ${ }^{\mathrm{e}}$ & 1 & NA & & \\
\hline \multicolumn{5}{|l|}{ Cover change frequency: } \\
\hline At least once in a week & 19 & 25 & $\mathrm{RR}^{\mathrm{b} \text { vs. a: }} 1.65$ & $1.03-2.66 ; 0.04$ \\
\hline $2-3$ times in a month ${ }^{b}$ & 10 & 4 & $\mathrm{RR}^{\text {cvs. a: }} 1.32$ & $0.17-10.2 ; 0.79$ \\
\hline 1 time or less in a month & 2 & 2 & $\mathrm{RR}^{\text {cvs. b. }} 0.70$ & $0.25-1.97 ; 0.49$ \\
\hline \multicolumn{5}{|l|}{ Sweeper type: } \\
\hline Dustbuster $^{\mathrm{a}}$ & 1 & 1 & $\mathrm{RR}^{\text {avs. b: }} 1.0$ & $0.24-4.1 ; 1.0$ \\
\hline Vacuum cleaner ${ }^{b}$ & 26 & 26 & $\mathrm{RR}^{\text {a vs.c. }} 1.25$ & $0.25-6.07 ; 0.78$ \\
\hline Watertank vacuumc & 4 & 6 & $\mathrm{RR}^{\text {bvs.c. }} 1.25$ & $0.56-2.80 ; 0.58$ \\
\hline
\end{tabular}

We asked about the kind of fabric used for the quilt and pillowcases. The distribution of the answers was as follows: $1(1.2 \%)$ of the participants preferred to use wool, $6(56.1 \%)$ of them preferred to use cotton, $14(17.1 \%)$ used synthetics, and 20 (24.4\%) of them use a mixture. The answers to questions about pillow type were as follows: 37 (45.1\%) used fibre, $21(25.6 \%)$ used cotton, $14(17.1 \%)$ used a mixture, 8 (9.8\%) used wool, and 2 (2.4\%) used other types. In the study, we could not evaluate the risk for all participants because some of them did not collect dust samples from home. For that reason, we calculated the risk ratio in a small sample group. The results showed that the encasement of the pillow affects the mite development risk, as shown in Table 3. Usage of wool pillowcases increases the mite development risk more than using fibre pillowcases and cotton pillowcases by 2 and 2.17 fold, respectively (Table 3 ). However, the material type inside of the pillow/quilt did not affect the risk of mite development (Table 3).

We evaluated the changing frequency of the quilts and pillowcases. The responders declared that they changed their quilts and pillowcases as follows: 49 (62.8\%) people once a week, 2 (2.6\%) of them 3 times a week, 4 (5.1\%) of them 2 times a week, 2 (17.9) of them 3 times a month, 14 (17.9) of them 2 times in a month, 5 (6.4\%) of them once a month, and $2(2.6 \%)$ people less than once a month. The results showed that the participants who changed their quilts and pillowcases $2-3$ times in a month 
TABLE 3. Association of building type, facade, and privacy properties with house dust development risk

\begin{tabular}{|c|c|c|c|c|}
\hline \multirow[t]{2}{*}{ Variables } & \multicolumn{2}{|c|}{ House mite } & \multirow[t]{2}{*}{ Relative risk ratio } & \multirow[t]{2}{*}{$95 \% \mathrm{Cl}, p$-value } \\
\hline & Presence & Absence & & \\
\hline \multicolumn{5}{|l|}{ Building type: } \\
\hline Brick $^{\mathrm{a}}$ & 31 & 30 & \multirow[t]{2}{*}{$\mathrm{RR}^{\text {a vs. b. }}: 0.66$} & \multirow[t]{2}{*}{$0.13-3.31 ; 0.61$} \\
\hline Stone $^{b}$ & 1 & 2 & & \\
\hline \multicolumn{5}{|l|}{ Building facade: } \\
\hline North $^{\mathrm{a}}$ & 14 & 12 & $\mathrm{RR}^{\text {a vs.b. }}: 1.22$ & $0.73-2.05 ; 0.45$ \\
\hline South $^{b}$ & 15 & 19 & $\mathrm{RR}^{\text {a vs.c. }} 1.39$ & $0.71-2.71 ; 0.33$ \\
\hline Otherc & 3 & 1 & R.R. ${ }^{\text {bv.c: }} 1.34$ & $0.71-2.55 ; 0.37$ \\
\hline \multicolumn{5}{|l|}{ Building privacy: } \\
\hline Detached building & 7 & 3 & \multirow[t]{2}{*}{ RR 1.51} & \multirow[t]{2}{*}{$0.91-2.49 ; 0.103$} \\
\hline Apartment & 25 & 29 & & \\
\hline
\end{tabular}

increased the mite development risk by 1.65 times when compared with the participants who change at least once a week $(\mathrm{RR}=1.65,95 \% \mathrm{CI}: 1.03-2.66, p=0.037)$ (Table 2$)$.

Seventy-two $(86.7 \%)$ of the 84 respondents had carpet in their bedroom, while 20 (23.8\%) of them preferred to use a rug. The results showed that mites developed 1.35 times more in the homes of participants who preferred to use carpets compared to other participants who preferred rugs, but the results were not statistically significant $(\mathrm{RR}=1.35,95 \% \mathrm{CI}: 0.53-3.44, p=0.52)$.

The building type, building frontage, and building privacy were also evaluated. None of these parameters affected mite development within the subgroups (Table 3 ). The answers given about the building type were as follows: 75 (91.5\%) of the buildings were brick, 5 (6.1\%) of them were stone, and 2 (2.4\%) of them were other types of buildings. The structure of the building did not influence the risk of mite development, as shown in Table 3. The question related to the facade of a building revealed the following: the southern facade $51.2 \%$, north facade $40.2 \%$, and the others were $8.5 \%$. The face of the building did not influence the risk of mite development, as shown in Table 3. Sixty-two (73.8\%) of the participants lived in the apartment, while $22(26.2 \%)$ of them lived in detached houses. The other risk-related question was "How many rooms do you have in your home?" Thirty-one $(37.3 \%)$ of the 84 respondents answered 3 rooms in the house, and 3 reported 4 rooms. Ten (12.0\%) of the participants had 2 rooms, $6(7.2 \%)$ of them had 5 rooms, $4(4.8 \%)$ of them had only 1 room, and $1(1.2 \%)$ person lived in a house with more than 6 rooms. The number of rooms did not influence the risk of mite development.

The responses to the question of which floor they lived on were as follows: $24(34.3 \%)$ people on the $3^{\text {rd }}$ floor, $19(27.1 \%)$ people on the $2^{\text {nd }}$ floor, $15(21.4 \%)$ people on the $1^{\text {st }}$ floor, $6(8.6 \%)$ people on the $4^{\text {th }}$ floor, $2(2.9 \%)$ peo- ple on the $5^{\text {th }}$ floor, $2(2.9 \%)$ people on the $6^{\text {th }}$ floor, and $2(2.9 \%)$ people on the $7^{\text {th }}$ floor. The floor of the house did not affect the risk of mite development.

We also evaluated the number of people at home. Responses to the question "How many people do you live with at home?" were as follows: $1(1.2 \%)$ person lived alone, 20 (24.4\%) people lived with 2 people, 35 (42.7\%) people lived 3 people, and 28 (31.7\%) people lived more than 3 people. The household numbers did not affect the risk of mite development.

Humidity is an important parameter for the development of house dust mites. Fourteen of the participants $(17.1 \%)$ reported that they had a humidity problem in their house. The humidity of the home increases the mite development risk by 1.74 times when compared to dry houses (Table 4).

Thus, we asked questions about their heating system. The answer to the question about the form of home heating were as follows: $60(73.2 \%)$ people had central heating, $21(25.6 \%)$ people used the stove, and $1(1.2 \%)$ person used an electric heater. The responses to the questions about the type of fuel used for heating purposes were as follows: $51.9 \%$ used natural gas, $33.3 \%$ used coal, $8.6 \%$ used mixed fuel, $4.9 \%$ used wood, and $1.2 \%$ used other fuel types. The type of heating and heating system did not influence the mite development risk (Table 4).

Thirty-nine (47.6\%) of the participants reported that they had flowers in the house. The presence of flowers or growing plants did not increase the mite development risk, as shown in Table 5. Aside from flower growing, some participants fed pets in their homes. The pet feeding rate was $16.9 \%(n=14)$. Six of the participants had fed animals for less than 1 year, 7 (\%50) of them had fed animals for $1-5$ years, and 1 (7.2\%) participant had fed pets for more than 5 years. Of 14 animal feeders only $42.85 \%$ cleaned the food containers every day. The result of our 
TABLE 4. Association of, humidity, heating system, and fuel type with house dust development risk

\begin{tabular}{|c|c|c|c|c|}
\hline \multirow[t]{2}{*}{ Variables } & \multicolumn{2}{|c|}{ House mite } & \multirow[t]{2}{*}{ Relative risk ratio } & \multirow[t]{2}{*}{$95 \% \mathrm{Cl}, p$-value } \\
\hline & Presence & Absence & & \\
\hline \multicolumn{5}{|l|}{ Humidity: } \\
\hline Yes & 7 & 2 & \multirow[t]{2}{*}{ RR: 1.74} & \multirow[t]{2}{*}{$1.105-2.74 ; 0.017$} \\
\hline No & 25 & 81 & & \\
\hline \multicolumn{5}{|l|}{ Heating system: } \\
\hline Stove & 7 & 6 & \multirow[t]{2}{*}{ RR: 1.08} & \multirow[t]{2}{*}{$0.61-1.91 ; 0.8$} \\
\hline Central heating & 25 & 25 & & \\
\hline \multicolumn{5}{|l|}{ Fuel type: } \\
\hline Natural gas ${ }^{\mathrm{a}}$ & 18 & 17 & $\mathrm{RR}^{\text {b vs. a. }} 0.93$ & $0.53-1.61 ; 0.79$ \\
\hline Charcoal $^{b}$ & 10 & 11 & $\mathrm{RR}^{\text {cvs. a. }} 0.97$ & $0.23-4.03 ; 0.97$ \\
\hline Wood & 1 & 1 & $\mathrm{RR}^{\text {b vs. c. }} 1.05$ & $0.25-4.51 ; 0.95$ \\
\hline Mixed $^{d}$ & 3 & 2 & & \\
\hline
\end{tabular}

study showed that pet feeding increased the mite development risk by 1.8 times $(\mathrm{RR}=1.8,95 \% \mathrm{CI}: 1.17-2.88$, $p=0.007$ ) (Table 5).

To evaluate the knowledge of the participant we asked "Where are the mites located?" According to the responses to the question about where the mites can be found, 36 (43.4\%) participants knew that mites were in human skin rash and cut nails.

The house dust mite was found in $32.5 \%$ of those with positive skin prick test results $(n=40)$ and in $7.3 \%$ of those with negative skin prick test results $(n=41)(p=$ 0.005, Fisher's Exact Test) (Table 6).

\section{DISCUSSION}

House dust mites are considered as major allergens responsible for the pathogenesis of diseases (bronchial asthma, allergic conjunctivitis, atopic dermatitis, allergic rhinitis, etc.), which affects the respiratory tract, eyes, and skin [14]. Recent studies showed that individuals with genetic variations are more prone to develop house dust-related allergic diseases [15]. The frequency of mites was found to be $21.4 \%$ in dust samples taken from the homes of these patients. The house dust mite frequency can be changed due to physical and climatic factors. In Turkey, the frequency of mites is reported to vary from $18 \%$ to $98 \%$ depending on factors such as the structure of the house, climate, and season of mites' collection [15-18]. This frequency of mites was found to be compatible with the rate of $18.6 \%$ in general in Turkey [16]. The frequency of house dust mites has been found at the rate of $16.9-90 \%$ in studies worldwide $[19,20]$. House dust mites are the most important allergen that triggers many allergic reactions such as asthma, eczema, and perennial allergic rhinitis. In our study, we evaluated if the risk of any kind of allergic diseases (atopic dermatitis, asthma, urticaria, allergic conjunctivitis, and allergic rhinitis) occurs more than others in the presence of house dust mites. The results showed that although house dust mites increase the prevalence of allergic diseases, they did not trigger any specific kind of allergic disease more than others (Table 1). The physical and climatic characteristics of the house influence the mite presence and density. Previous studies have confirmed that the risk factors that increase the mite density are as follows: warm and humid conditions, building structure and frontage (more predominant in bungalows than flats, also frequency higher in the southern part), ventilation type and aeration frequency, vacuum cleaner type and vacuuming frequency, the number of people living at home, smoking at home, and animal nutrition in the home or garden.

Previous studies have shown a positive correlation with mite frequency and the following conditions: using the stove at home, being a detached house, brick building structure or having a more significant number of living people at home, lack of ventilation of the room, no vacuum cleaner used in cleaning, smoking at home, and animal nutrition in the home or garden $[18,21]$. Also, no significant association was found between the presence of mite and factors such as the total number of floors in the house, warming type and the shape of the house, the number of living people in the house, smoking at home, plants at home, and animal nutrition in the home. There is some debate about house dust development risk and dust-related parameters such as smoking at home, building type, and structure, and feeding flowers and animals. We evaluated all possible risk factors (smoking at home, sweeping frequency at home, ventilation frequency of rooms, building structure, height of the home, and others) in surveys. The current results of our study indicate 
TABLE 5. Association of plant growth and animal feeding with house dust development risk

\begin{tabular}{|c|c|c|c|c|}
\hline \multirow[t]{2}{*}{ Variables } & \multicolumn{2}{|c|}{ House mite } & \multirow[t]{2}{*}{ Relative risk ratio } & \multirow[t]{2}{*}{$95 \% \mathrm{Cl}, p$-value } \\
\hline & Presence & Absence & & \\
\hline \multicolumn{5}{|c|}{ Plant growth: } \\
\hline Yes & 18 & 13 & \multirow[t]{2}{*}{ RR: 1.37} & \multirow[t]{2}{*}{$0.83-2.25 ; 0.216$} \\
\hline No & 14 & 19 & & \\
\hline \multicolumn{5}{|c|}{ Animal feed: } \\
\hline Yes & 14 & 5 & \multirow[b]{2}{*}{ RR: 1.82} & \multirow[b]{2}{*}{$1.76-2.83 ;<0.007$} \\
\hline No & 19 & 28 & & \\
\hline
\end{tabular}

TABLE 6. The prick test results and house dust presence of the participants ( $n$ - number; $\%$ - percent)

\begin{tabular}{|l|c|c|c|}
\hline \multirow{2}{*}{$\begin{array}{l}\text { House } \\
\text { dust mite }\end{array}$} & \multicolumn{2}{|c|}{ Prick test results } & \multirow{2}{*}{ P-value } \\
\cline { 2 - 3 } & Positive, $n(\%)$ & Negative, $n(\%)$ & \\
\hline Positive & $13(32.5)$ & $3(7.3)$ & \multirow{2}{*}{0.062} \\
\hline Negative & $27(67.5)$ & $38(92.7)$ & \\
\hline Total & $40(100.0)$ & $41(100.0)$ & \\
\hline
\end{tabular}

no correlation between mite frequency and factors such as detached house or apartment; the floor, façade, and construction material of the building, the heating system and fuel type, cohabitants in the house, current smoking status, inhalation of smoke, and growing flowers. There are conflicting results in the literature about house dust presence and animal feeding. In contrast, we found that feeding animals increases the house mite development risk by 1.82 fold compared with patients who did not have a pet $(\mathrm{RR}=1.82, p<0.001)$. The best survival and population development conditions for house dust mites are warm (65 F-80 F) and humid (RF above 55\%) places. Daily activities such as cooking and bathing increase the relative humidity; thus, aeration of the rooms is necessary to decrease the relative humidity.

In our study, we could not find a statistically significant association between the aeration period and mite provenance. In fact, we need to evaluate not only the aeration period but also the duration to obtain accurate results. The current results indicate a strong correlation between the pillowcase and duvet cover material with mite frequency. We clearly found that the pillowcase and duvet cover affect the presence of the mites. In this study, we found that a wool pillowcase increases the mite risk 2.2 and 2 times more than cotton and fibre pillowcases, respectively. In contrast, no association was found between wadding material and mite development risk. The duvet/pillow covers seal the allergens, thus providing a barrier function between human skin and made-off $100 \%$ cotton fabric materials. In our study, we showed that the cleaning frequency of pillowcases was negatively correlated with mite development. The weak point of our study was that the house dust samples were not taken seasonally. A prick test is used to determine the antigens of $D$. pteronyssinus and $D$. farinae for house dust mites all over the world. It helps to clarify the role of mites in allergic diseases. It has been reported that skin test positivity to house dust mites varies between 35\% and 99\% among patients with allergy complaints. In our study, we requested dust samples from participants. Sixty-six of the participants collected the dust, and we found mite samples in 50\% $(n=33)$ of them. On the other hand, we determined the prevalence of the mites as $32.5 \%$ in the prick test. In our study, we showed that $D$. pteronyssinus and D. farinae are common (32.5\%) but are not the only species in dust samples. $17.5 \%$ of the house mite allergens could not be identified without microscopic examination. The Dermatophagoides genus was seen in all house dust samples in patients with a house dust allergy. The vitality and mobility of the mites were important to identify the genus of the mite. Although we expected to see another genus, seasonal factors, sample collection, and storage conditions during the carriage to the hospital may be affected by the vitality of the mites. Atambay et al. showed that the negative prick test does not show that mites were not in the home, and a positive test result does not show that mites were in the home [22]; we also proved this information in our study. As a result, allergic diseases are gradually increasing in Turkey as well as the whole world. House dust mites are considered the most important source of dust allergens. ELISA is a powerful tool to determine the level of house dust mites and their allergens, and it is important to correlate the mite allergen level and asthmatic attacks.

\section{CONCLUSIONS}

In the presence of dust-related allergic diseases, the dermatologist should be requested to take dust samples from home for detailed examination such as microscopy or ELISA. The patients' knowledge about relationships with different housing characteristics, climate and cleaning conditions, and mite allergy must be increased for effective allergen elimination. 


\section{CONFLICT OF INTEREST}

The authors declare no conflict of interest.

\section{REFERENCES}

1. Kupryś-Lipinska I, Kuna P. Severe uncontrolled allergic eosinophilic asthma looking for the best therapeutic option. Alergol Pol 2020; 7: 180-9.

2. Kapur C, Shenoi SD, Prabhu SS, et al. Patch testing with dermatophagoides and its correlation with chronic eczema and atopic dermatitis. Indian J Dermatol 2009; 54: 243-6.

3. Handa S, De D, Mahajan R. Airborne contact dermatitis - current perspectives in etiopathogenesis and management. Indian J Dermatol 2011; 56: 700-6.

4. Calvo M, Fernández-Caldas E, Arellano P, et al. Mite allergen exposure, sensitisation and clinical symptoms in Valdivia, Chile. J Investig Allergol Clin Immunol 2005; 15: 189-96.

5. Jąkalski M, Bożek A, Mangold D, et al. Problem of nonresponse to allergen immunotherapy. Alergol Pol 2019; 6: 134-40.

6. Arlian LG, Elder BL, Morgan MS. House dust mite extracts activate cultured human dermal endothelial cells to express adhesion molecules and secrete cytokines. J Med Entomol 2009; 46: 595-604.

7. Bisen N, Shenoi SD, Balachandran C. Aeroallergen patch testing in patients of suspected contact dermatitis. Indian J Dermatol 2014; 59: $252-6$.

8. Jeong SK, Kim HJ, Youm JK, et al. Mite and cockroach allergens activate protease-activated receptor 2 and delay epidermal permeability barrier recovery. J Invest Dermatol 2008; 128: 1930-9.

9. Cui Y. When mites attack: domestic mites are not just allergens. Parasit Vectors 2014; 7: 411.

10. Wiwanitkit V. House dust mite allergy immunotherapy tablet. J Investig Allergol Clin Immunol 2015; 25: 83.

11. Bręborowicz A. Efficacy of allergen immunotherapy and evaluation methods. Relation to specific allergen and route of administration. Alergol Pol 2018; 5: 186-91.

12. Pawliczak R. Skin prick test and patient informed consent. Alergol Pol 2020; 7: 47-52.

13. Spieksma FT, Spieksma-Boezeman MI. The mite fauna of house dust with particular reference to the house-dust mite Dermatophagoides pteronyssinus (Trouessart, 1897) (Psoroptidae: Sarcoptiformes). Acarologia 1967; 9: 226-41.

14. Medeiros M, Figueiredo JP, Almeida MC, et al. Association between mite allergen (Der p 1, Der f 1, Blo t 5) levels and microscopic identification of mites or skin prick test results in asthmatic subjects. Int Arch Allergy Immunol 2002; 129: 237-41.

15. Kowal K, Bodzenta-Lukaszyk A, Pampuch A, et al. Analysis of -675 $4 \mathrm{~g} / 5$ G SERPINE1 and C-159T CD14 polymorphisms in house dust mite-allergic asthma patients. J Investig Allergol Clin Immunol 2008; 18: 284-92.

16. Kalpaklioğlu AF, Emekçi M, Ferizli A, et al; House-Dust Mite Working Group. A survey of acarofauna in Turkey: comparison of seven different geographic regions. Allergy Asthma Proc 2004; 25: 185-90.

17. Akdemir C, Gürdal, H. Kütahya'da Ev Tozu Akarları. Türkiye Parazitoloji Dergisi 2005; 29: 110-5.

18. Güleğen E, Gırışgın O, Kütükoğlu F, et al. Bursa evlerinde bulunan ev tozu akar türleri. Turkiye Parazitol Derg 2005; 29: 185-7.
19. Vesper S, Choi H, Perzanowski MS, et al. Mold populations and dust mite allergen concentrations in house dust samples from across Puerto Rico. Int J Environ Health Res 2016; 26: 198-207.

20. Ree HI, Jeon SH, Lee IY, et al. Fauna and geographical distribution of house dust mites in Korea. Korean J Parasitol 1997; 35: 9-17.

21. Aycan OM, Atambay M, Daldal UN. Ev tozu akarlarinin görülme durumunun sosyal değişkenler açisindan incelenmesi. Turkiye Parazitol Derg 2007; 31: 219-24.

22. Atambay M, Aycan MÖ, Daldal N. Malatya'da ev tozu akar faunası. Turkiye Parazitol Derg 2006; 30: 205-8. 